\title{
POST-TRUTH FROM THE PERSPECTIVE OF HANNAH ARENDT'S POLITICAL THEORY
}

DOROTA SEPCZYŃSKA, Institiute of Philosophy, The Faculty of Humanities, University Warmia and Mazury, Olsztyn, Poland

SEPCZYŃSKA, D.: Post-Truth from the Perspective of Hannah Arendt's Political Theory

FILOZOFIA, 74, 2019, No 3, pp. $209-222$

This paper constitutes an attempt at analyzing the phenomenon of post-truth from the perspective of the political thought of Hannah Arendt. It discusses the hypothesis: the problem of post-truth in politics had been described by Arendt before the term "post-truth" appeared. The applied methodology consists of the analysis of source texts inspired by hermeneutics, history of ideas and Arendtian narrative on politics.

Keywords: Post-truth - Politics - Modern lie - Deliberate falsehood - Subjective

$$
\text { opinion }-\mathrm{H} \text {. Arendt }
$$

I.

It is commonly agreed that we live in the era of post-truth, which started almost at the same time as the very term "post-truth" came into being, that is at the turn of the 20th and 21 st century. Journalists and scientists differ as to the details concerning the issue in question. Its beginning is sometimes associated with the Watergate and Irangate scandals; others see it in Brexit, while still others in presidential elections in the USA in which Donald Trump was a candidate.

In short, it is claimed that the politics of post-truth appears in political culture in which a considerable part of society accepts the technique of exercising power and leadership which depends on referring to statements which ignore or negate facts, and to personal opinions. Its core depends on the coexistence of political lie and marginalization of the importance of differences between truth and falsehood, feelings and reason, or the total lack of such differences. Post-truthfulness differs from simple negation of truth, as the latter posits significance of truth and its distinctiveness from falsehood. Post-truthfulness consists of usurping, often appealing to emotions, that falsehood and private convictions are truth and it is based on the invalidity of this distinctiveness. Hence the prefix 'post' should be referred to the period of political culture in which truth and truthfulness have ceased to be important for many people, 
which is eagerly used by politicians (The Oxford Dictionaries; Macintyre). This is a doubtlessly worrying phenomenon, but is it new? What forms does it assume? (II) What are its causes? (III) Can we overcome it? (IV)

\section{II.}

The history of political theory and practice shows that since antiquity there has been a conflict between factual truth and politics. According to Hannah Arendt, factual truth is the conformity of thoughts with facts and events, i.e. with what is or what was. It is determined on the basis of reports of eye witnesses, documents, sources, monuments (Arendt 1985, 159, 170). Its opposite is lie and deliberate falsehood. Factual truth is strictly related to truthfulness understood as conformity of the message with what is real and not with what is possible or fictional. This conformity is guaranteed by honesty, independence and impartiality $(160,176)$.

The lie has almost always been a tool of politicians. However, according to Arendt, it can appear in two forms: traditional and modern. The traditional political lie consists in hiding - it usually assumed the form of a secret kept by rulers who did not wish to reveal information to their enemies. It referred to particular issues of international politics and was used by diplomats in situations of clear and direct threat. This lie was not supposed to deceive everyone (Arendt 1985, 163, 178 - 179), so it did not negate the difference between truth and falsehood. Such a lie was believed to be useful and bring benefits.

The modern political lie is deliberate falsehood - it is a manipulation of facts, forged fiction which demonstrates itself in rewriting history, in creating an image of the politician. It is to have effect in foreign affairs and internal affairs - it is related to non-distinguishability of falsehood from truth. It manifests itself in stereotypes, propaganda and indoctrination. Its essence consists in negating facts, i.e. reality. Because of appropriate social conditions, application of modern techniques and the mass media, what is made up shapes the views of some group of people, e.g. all the citizens of a given state, or goes beyond its borders (Arendt 1985, 184). Aiming at destroying what it negates, it introduces an element of violence into the world of politics.

In the modern times, not without the contribution of the Middle Ages, people tend to equate politics with naked force and violence, coercion (Arendt 1985, 178 181; Arendt 2007, $130-178,212-221$ ). According to Arendt, these are superstitions which turn the sense of politics into nonsense, they mistake politics with what annihilates it. Considering the categories of the source and internal meaning related to the political form of the ancient polis, politics in not immoral, partial and oppressive. Politics is a space "between" people which is created by people in the process of discussion, cooperation and coexistence. Political activity is based on ideological 
pluralism, yet it consists in uniting (Arendt 2007, 125 - 127, 151; Arendt 2000, 12, 216). This is why politics is the only common matter, in politics differentiating features are suspended. Dialogue is possible only in a relationship with others, it is dialogue that constitutes and maintains the existence of the space between people (Arendt 2007, $214-215$ ). Using language which is comprehensible for everyone, citizens discuss problems concerning everyone and solve these problems acting together. It is a hallmark of political thinking to take into account the views of others; a citizen shapes his own views on a given matter considering them from the perspective of people who have different interests and views. Equality and impartiality are conditions of political thinking, i.e. discursive and representational thinking. Equality means that everyone has an equal right to participate in government which most often assumes the form of discussion. That is why equality consists primarily in an equal right to speak, express one's views and listen to others (Arendt 2007, 147). In turn, impartiality depends on freeing oneself from personal interests, from the point of view determined by a particular position in the world. The degree of impartiality determines the quality of political judgement and opinion, impartiality also allows one to grasp the objective world (Arendt 2007, 156; Arendt 1985, 168 - 169).

Force and violence destroy politics. They appear in politics in line with thinking and acting which are governed by particularistic interests. Politics differs from nature and the private sphere, i.e. economy and family, whose essence lies in taking care of one's own interests, the interests of one's family and the benefit of one's milieu. Introducing partial interests in interpersonal space is connected with defining politics as a means to an end which is beyond politics, while it is not a means to any higher end (Arendt 2007, $144-178,212-221$ ). The tissue and sense of everything that is political amount to freedom understood as verbally and actively entering relationships which lack force and violence, coercion of biological life and coercion coming from other people. These relationships are equal to experiencing the diversity of the world as a whole and to spontaneously beginning something new (Arendt 2007, 146, $150,154,157,169)$.

Force and violence are opposites of power. Power corresponds to the human ability not just to act but to act in concert; it is not the property of an individual, it is an ability (potestas) to create a community which gives power its legitimacy. Power exists as long as there is a community, i.e. as long as people shape their common opinion in rational dialogue and realize it in cooperation. Force and violence are phenomena characteristic of an individual or a small group, they are related to the direct rule of men over men, coercion, non-voluntary obedience, killing. When force and violence are introduced into the space between people, political institutions become instruments of 
interest groups in realizing their particularistic goals. These goals function as a justification for using force and violence (Arendt 2007, 214 - 215).

Already in 1951 Arendt claimed that in the modern age we deal with organized lying which spreads in the entire political sphere on a massive scale (Arendt 2014, $389,416,432$ - 434; Arendt 1985, 160). She believes this phenomenon to be reprehensible and dangerous. In 1967 she observed that organized lying is used in tyrannies, dictatorships (class, partisan and military dictatorships), and totalitarian governments as well as free societies in which governments or influential organizations (e.g. social movements, political parties, churches) want to replace reality with fiction or transform truth into opinion (Arendt 1985, 163, 183).

Let us now consider the second case. Firstly, it must be determined what is defined as opinion. It is a conviction about something, a view on a given matter. We can distinguish personal views, group opinions and public opinion. They differ only in the range of acceptance. Public opinion is most general. According to Arendt, politics is not based on personal views or the opinion of a group who achieved hegemony by sheer numbers, cunning or violence, but it consists in a shared ethical-political view of citizens achieved in real and imagined dialogue. Considering a fundamental issue citizens take into account the points of view of other people - they imagine what they would want, what they would think if they were these people. Thus reaching a common political opinion depends on impartiality and cooperation.

In Arendt's view factual truth and political opinion belong to the same reality (the common life of people), yet they are not the same. Let us consider their permanence and manner of legitimacy. Truth is permanent, opinion undergoes changes this refers to fluid human matters, circumstances which are incidental, inconsistent and not entirely transparent for the human mind. Opinion is legitimized by agreement following discussion, which is indispensable when there is a number of views and interests; factual truth lies beyond agreements, it is an existing state of affairs. Opinion stems from factual truth, and factual truth validates opinion (Arendt 1985, 165, 170; Arendt 2005, 382). However, political opinion is not a falsehood, it is rather a stable moral-political consensus which concerns justice, it is practical rationality which is valid thanks to impartiality. Truth cannot become a subject of discussion or persuasion. However, political opinion is not a falsehood; on the contrary, it is a stable moral and political consensus which concerns solidarity, it is practical rationality which has a cognitive aspect which is possible due to impartiality. Political opinion expresses moral knowledge, but it cannot be equated with truth. Personal and group views can be lies, and purposeful fiction; political opinion cannot be that - it is an effect of agreement, i.e. voluntary consent reached thanks to impartiality. 
Arendt believes that totalitarian rule did not occur out of nothing, but was born at the beginning of the 20th century originating in monopartisan dictatorships, which in turn originated as a result of the totalitarian movement in the modern democratic state (Arendt 2014, 537; Arendt 1985, 140). Totalitarian rule originated because economy had conquered the political sphere, and common political interest had been subjugated to the interests of capital groups. This provided conditions for the occurrence of longlasting social changes, changes in the way of thinking and perceiving the reality, changes facilitating the origination of ideologies, mass movements (including totalitarian ones) and ultimately totalitarian rule. Totalitarian movements, such as tyrannies and dictatorships, used primarily propaganda. These were lies more subtle than those of totalitarian rule. Apart from this, in totalitarian rule propaganda was used rather externally, since in internal affairs indoctrination related to terror appeared (Arendt 2014, $384,424-425)$.

Both the sphere of politics and the sphere of private life were destroyed; people could not have their own views on the ideas preached by the party and the government (Arendt 2014, 422-423). The real aim of the totalitarian lie was not only to convince atomized individuals, but also to organize them (Arendt 2014, 441, 443).

Irrespective of whether totalitarianism was rightist or leftist, the imagined world dominated reality more consistently and on a greater scale than in other despotic systems. Life under totalitarian rule was completely subjugated to fiction. Not merely single facts but their wide range were negated. If a totalitarian government did not agree to a fact, it was not satisfied with asserting that something did not exist (e.g. unemployment), but in practice it acted as if the fact had not existed at all (e.g. unemployment benefits were abolished - Arendt 2014, 423). People believed to be enemies were not only pushed into oblivion, but they were obliterated from the surface of the Earth.

The propaganda of totalitarian movements lies referred to what was ignored or hidden by the establishment, i.e. old political parties and views dominant in society. These were sensations concerning scandals and corruption in the higher echelons of society (Arendt 2014, 432, 435). It focused on assertions of the infallibility of its own prophesies which boiled down to 'discovering' hidden powers (Arendt 2014, 431), veiled threats against everyone (Arendt 2014, 426), references to the scientific character of its own assertions, and persuading that only future could reveal their significance (Arendt 2014, 426 - 427). Most often this was based on conspiracy theories which were authenticated by inserting an element of probability in the fiction. This was possible since some empirical data which were verifiable (e.g. the public influence of Jews in the past) were used and generalized in spheres distant from the area controlled by experience (international Jewish conspiracy aimed at ruling the world - Arendt 2014, 442). 


\section{III.}

Modern lies in democratic and despotic countries cases what is used is ideological thinking which appeared in the 19th century, among others in the form of imperialism, communism, and nationalism (Arendt 1985, 163). What are its characteristics? First of all, it aspires to explain reality in its entirety, that is all the historical events, everything that was, is and will be. It perceives history as a movement which undergoes the 'law' of idea indicated by a given ideology (Arendt 2014, 549). Secondly, it is a kind of thinking independent from experience and reality perceived with the senses. It speaks about the hidden meaning of political events and conspiracies. Considering the current reality to be false, it articulates the 'real' reality, which is in fact imagined. Access to this reality is possible only if one is subject to propaganda and indoctrination (Arendt 2014, 549 - 550). Thirdly, in ideological thinking thought becomes independent from reality thanks to certain leadership methods, which are logical and deductive reasoning. The world in which we live is not logical, consistent and organized, the 'real' reality is. The former is incomprehensible, it encompasses coincidence; the latter is fully transparent to human reason, because it is created by human reason (Arendt 2014, 442, 549 - 551; Arendt 1985, 178). In this way simplifications appears; unemployment, low income, lack of sense of safety can be attributed to some others who are a minority, who are stateless people.

Apart from this, modern lying, irrespective of the form of government, has the same social source, namely spreading of the mob and appearance of the masses. People socially uprooted and superfluous, gullible and cynical were the creators and recipients of the invented fictions (Arendt 2014, 460), for them the difference between fact and fiction did not exist or was not important. The mob used mass propaganda giving rise to numerous nationalist and racist pan-movements (e.g. Pan-Germanism, Pan-Slavism) which were later transformed into totalitarian movements, which in turn were eagerly supported by the masses. Members of this groups do not identify themselves with political society, they do not feel of it part. Because they are threatened by unemployment, they are migrants or people devoid of protection, they do not have any political representation. Hence they reject the party system, they are hostile towards the state in general and negate the existing social class system (Arendt 2014, $206-217,399,432-433)$. They undertake primarily extra-parliamentary action. They openly accept partiality and even using violence against others. While citizens are united by a common opinion about the most fundamental matters reached through dialogue, the mob is bound by negative emotions: frustrations, xenophobia, hatred, hatred (Arendt 2014, 296). They include individuals who are politically atomized, who have lost their social status and in line with it their bonds with others. Atomization means that people do not cooperate; this leads to helplessness (Arendt 2014, 553 
- 556) resulting from the disappearance of solidarity and communicative power which stems from discursively shaping the opinions of citizens who have equal rights. In such a situation only administrative power relying on violence remains. In order to understand the abandoning of common matters, the origination of mass movements and the acceptance of modern political lie, according to Arendt, it is important to take into account the fact that man is totally colonized by work aimed at earning money, work which is becoming the most crucial source of identity (Arendt 2014,555). Politics accepts the infinite potential of every single human being, while economy accepts only the element which is related to production. When politics becomes an instrument of economy, people become reduced to the labor they do, and are indistinguishable from and replaceable by others.

Arendt claims that when ideological thinking is combined with coercion, isolation becomes loneliness in social life. At its extreme, this process results in the destruction of private life, the relationships of people with other people and reality, and in line with that, an ability to think freely, critically and reasonably disappears (Arendt 2014, 553, 559).

IV.

In Arendt's view, are the institutions which ensure factual truth and truthfulness, these are primarily courts, higher education institutions, expert scientific institutions and arts (Arendt 1985, 186-189). ${ }^{1}$ They protect truth on condition that they are independent from political power, economic lobbyists and the expectations of various social groups. Saying that, Arendt believes that what occurs in liberal democracy is politics, not its ersatz. Liberal democracy is a system which is governed by constitutionalism, a rule of controlling and balancing power, interdependence of subjective freedom and political freedom (Arendt 2007, 158 - 162). Naturally, she recommends that its institutions free themselves from the domination of economy over politics. She also adds a demand for abandoning the parliamentary system in favor of the federation of direct democracies. In her opinion, politics most clearly reveals itself if there is local "faceto-face" self-government, active citizenship, associations of free and equal people who have free time.

From the perspective of Arendt's theory, a remedy for post-truth in politics does not consist in embracing truth as the chief political value, or increasing the number of scientists in parliamentary committees. Politics has to be defended against post-

\footnotetext{
${ }^{1}$ Arendt believes that the function of the media is to inform, to present factual truth, and not to create a space for building common opinion, filtering personal opinions and generalizing them into political opinion. If the press was to become the fourth estate, it should be protected against the power of the people more than the judiciary (Arendt 1985, 187).
} 
truth, but sometimes it must be defended also against truth, since not every truth is politically innocent. Current political problems stem not only from modern lying, which depends on replacing reality with fiction and truth with opinion, but also from replacing political opinion with particular opinions which are very often presented and treated as truths. Arendt explicitly claims that antagonism occurs not only between factual truth and politics; politics has come into conflict also with philosophical truth, religious truth and scientific truth (Arendt 1985, 159). However, politics is not always to blame for this.

Discord between philosophy and politics appeared first. As a matter of fact, these are two disparate manners of human existence which are related to disparate kinds of reasoning. A philosopher looks for an eternal and absolute truth alone. A citizen in dialogue with many other citizens reaches merely changeable and relative opinion. Opinion is the opposite of truth. Truth is apolitical, non-discursive, and it cannot be subject to consensus, and it is not important for its existence how many people accept it. The content of a true statement is in its nature coercion, which is why truth will always be suspicious from the perspective of politics. Power based on coercion wants its subjects to bend in a servile bow, while philosophers bend only before truth, which is why philosophical truth makes it impossible for tyrants to have a monopoly on coercion. In turn, power based on consensus excludes coercion. Demanding truth in the space between people undermines the foundation of politics discussion. Additionally, direct interference of philosophy into politics transforms truth into opinion (Arendt 1985, 160 - 164, 168 - 175).

Religious 'truths' are in fact views which are absolutely binding in a given community of believers. Thus these truths are particularistic opinions which bind the community of believers, but they do not bind all the citizens or people. However, what appears in politics is common opinion. Apart from that, 'religious' truth is apolitical. Looking at politics from the perspective of a visible church meant taking a position outside politics, and looking at politics from the perspective of an invisible church above it. God and other religious categories go beyond the sphere of interpersonal relationships, they are outside of, and above, people, not between them (Arendt 1985, 173 - 174). Political notions (among others: freedom, equality, power) are not of religious origin (Arendt 2005, $372-373$ ).

In its Christian interpretation, politics becomes a means to achieve higher goals, and power becomes management. Christianity laid a foundation for the space which was public but not political (Arendt 2005, 372, 384; 2007, 163 - 168).

Arendt claims that in the modern world the antinomies between truth of religion and truth of philosophy, on the one hand, and politics, on the other hand, disappeared. In the case of philosophy, controversies appeared in Antiquity and at the beginning 
of the Modern Era, but they subsided in the Enlightenment. First of all, philosophers started replacing truth with opinion, assuming that truth is not given or discovered, but generated by people in dialogue. Secondly, they abandoned Platonian dreams of rule. Tyrannies of philosophical truth appear almost only in political utopias. Those who use theories in which truth and truthfulness are irrelevant as their political weapon are not philosophers but ideologists (Arendt 1985, 159-163, 172-173).

When it comes to religion, its conflict with politics led to the separation of church and state, in fact Christian religion and politics (Arendt 1985, 162 - 163). In the West, political secularism appeared and it brought a lot of good to both believers and non-believers. In political secularism religion and religious institutions are not a binding authority for those in power; political life is not sanctioned by religion. This does not mean that political secularism was accompanied in its appearance and development by spiritual secularism. People did not become less religious, religion did not close itself in the 'inner' world (Arendt 2005, 372, 379, 384, 388).

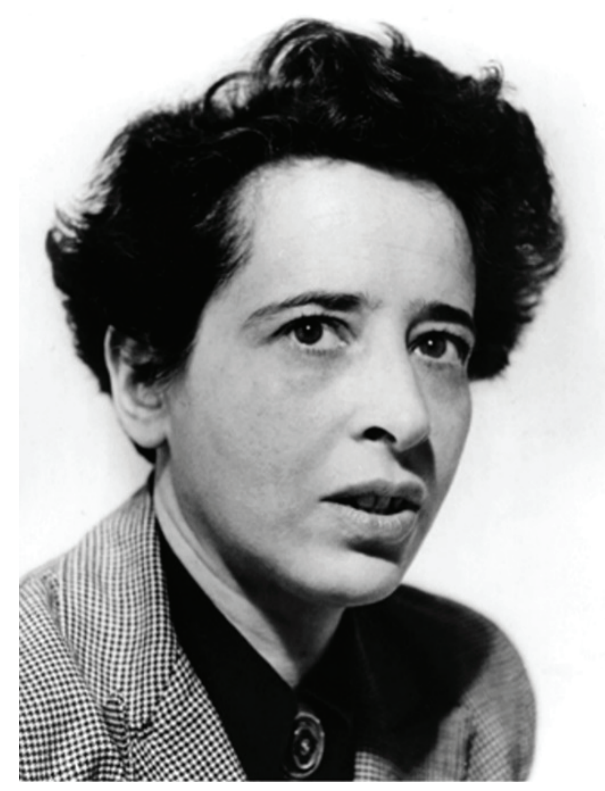

Hannah Arendt. Neznámy autor, platí licencia $\underline{\mathrm{CC} B Y-\mathrm{SA}-\mathrm{NC}}$

In the 1950s and 1960s Arendt states that the dispute between politics and philosophy, as well as between politics and religion is solved when facts are considered. This does not mean, however, that she does not admit the possibility of change an these situations. One needs to remember that she believes that what was before can come back, as it remains in reality as an eternally present potential (Arendt 2014, 560). Apart from this, Arendt expresses a few comments on another 'union' between religion and politics in Religion and Politics (Arendt 2005, 377, 384).

From the perspective of Arendt's thought we are still threatened by philosophical, scientific and religious ideologies. 'Philosophical' theories are used as the basis for political order, a justification for political decisions. Philosophers in the 17th century found a way to terminate the conflict between religion and politics, yet it appeared that there was a problem to accept this route. It soon appeared that the process of secularization of politics in the West was not inevitable. Religious groups did not lose political aspirations; such 
aspirations go beyond the private sphere in the demands of populist movements, party programs, declarations and decisions of politicians or terrorist acts. Objective truthfulness is replaced by subjective truthfulness, which makes a pretense of indicating and justifying the goal of politics. Subjective truthfulness should be qualified as a statement about authenticity, and honesty, but not truth. This monologic thinking which does not grasp the entirety of the world shows it only from the perspective which corresponds to this thinking's position in the world, a position which determines of. If post-truth is also replacement of truth about facts with individual or group opinion, the conflict does not appear only between different understandings of truth and politics, but also between truth about facts and religious truth. Is not the truth of ideology a modern lie, that is post-truth? Is not post-truth related to post-secularism?

According to Arendt, all truths are contradictory to political opinion when it comes to establishing their validity; from the perspective of politics all truths have despotic predilections. The content of a true statement is by nature coercion, demanding acceptance peremptorily and precluding debate, while it is the essence of political life to discuss matters and consider other people's opinions. Differences between truth and opinion depend on the fact that expressing the former means opacity, and the latter clarity. Let us take for instance truth about facts which does not lend itself to further explanations (Arendt 1985, $168-170$ ).

Truth is not a political value; political values include freedom, equality, solidarity and justice which is founded upon common impartial opinion. A people seeking truth are not a political persons, a people of action. They pursues truth outside the area of politics. The conditions that must be then fulfilled include: the solitude of a philosopher, scientist and artist; impartiality of a historian and judge; independence of witnesses, reporters and those seeking facts. The impartiality is not political, it is rather a feature of a position of someone from outside, someone who is not politically engaged, someone who is not devoted to any cause. If a truth advocate endeavors to interfere in politics using persuasion or violence, he does not advocate truth (Arendt $1985,173,176-177,185-186)$. Apart from this, if he shapes his opinion in a way which takes into account only his own interests or interests of the group to which he belongs, this is rooted in lack of imagination and inadequacies of power of judgement (Arendt 1985, 169).

This does not mean that we should exclude truth from politics entirely. Philosophical and religious truths (especially those referring to ethics, e.g. the goodness of Jesus of Nazareth or Francis of Assisi) can enter politics only via examples which teach or inspire. Only in this way can they be legitimized and verified (Arendt 1985, $174-175)$. Scientific truths and truths about facts have important tasks to fulfill in politics. Apart from the alienating aspect of technology and modern scientific 
cognition, Arendt notices that man-made objects build the world of man in which activity and dialogue can appear, that is politics can appear (Arendt 2000). Truths about facts concern matters significant in politics in a direct manner, they condition political thought and inspire people's actions, as they are material for their opinions. Apart from this, opinions are legitimate as long as they respect facts (Arendt 1985, $163,165,169-170)$. All truths control power. The actions of those in power are legitimate when they are in accordance with a constitution, a bill of rights, the rule of separation of powers, but also when they take into account facts, axioms of scientific discoveries, and when they make it possible to seek and spread truths in the non-political public sphere without social and political pressures (Arendt 1985, $165-166,168$ ).

\section{V.}

Hannah Arendt can be perceived to be a forerunner of critical analysis of the problems of post-truth. She does not apply the term 'post-truth', yet she talks about the modern political lie which is equated with what we know today as 'post-truth.' She describes a phenomenon which consists in replacing facts with fiction, transforming truth into opinion, and opinion into truth. This phenomenon is present in rewriting history, creating an image of the politician. Its mass nature is threefold - it is to fool everyone, it employs the mass media, and it is a practice accepted by the masses, for whom there is no difference between facts and fiction, emotions and reason, or for whom such a difference is not significant.

From the perspective of Arendt's theory, post-truth is related to post-politics. It is not post-truth that transforms politics into post-politics, it is post-politics that generates post-truth. When the signifycance of differentiation between power and violence, dialogue and monologue, impartiality and partiality, common and private interest, citizens and the masses consuming goods and state administration service disappears, then the cynicism which rejects belief in any truth appears and the power of judgement thanks to which we find our bearings in the world is destroyed, e.g. we differentiate between truth and falsehood. In post-politics in Arendt's understanding, state administration serves the private sphere - the interests of capital groups or/and religious groups. There is a gradual erosion of values and political institutions: freedom, equality, solidarity, communicative power.

Post-truth is an element of the populist revolution in the name of social cause which transforms political power into violence. It originates in deep social and mental changes. They occur when the market, which administrative power serves, conquers the sphere focused on reaching agreement, related to discursive thinking and communicative power. This generates circumstances facilitating expansion of the mob and the masses, and in turn ideologies and populist movements. Victims of social 
exclusion, who lack safety resulting from having paid jobs, are creators and sympathizers of post-truth. These are atomized individuals who act with their individual interest in mind. These people have lost trust in political institutions and in the sense of importance of the difference between truth and fiction, private views and political common opinion. They expect simple explanations and solutions. The mob and the masses both lack the virtue of citizenship which consists not only in being engaged in political matters, but also in listening to others, in the willingness to explain and justify things in categories acceptable for everyone, in lack of partiality when taking decisions which concern everyone, and in being open to changing one's own views. These people are bound by ideological thinking and negative emotions (hatred towards elites and others, fear, frustration, xenophobia, irrational notions, base instincts and the feeling of helplessness).

Do we not deal with the process of business conquering politics also at present? Is not economic globalization a new form of expressing imperialistic ambitions? Have not corporations freed capital from political power and become the actual sovereign? Is not the mob a founder of populist movements and right-wing parties? Are not the masses their sympathizers? Does postmodern populism differ from modern populism? We must be careful for post-truth not to lead to totalitarianism.

I also claim that in the case of Arendt truth is the highest value in the domain proper for itself, yet its full existence in politics is impossible and improper as it endangers both truth and politics - the permanent integration of ideological diversity. Truth is neither a political value, nor a chief value introducing order in politics. It is also not discovered in the political process, while political power should not be a tool for its dissemination. Truth should be independent of the will of the people and political powers, as well as economic pressure. Truth is related to both freedom from politics and independence; it should be sought and proclaimed in the non-political sphere. At the same time, Arendt indicates that truth is not unimportant in politics. She observes that in political life there are certain forms of truth.

She does not entirely separate thinking (in the broad sense of the word) from action. Vita contemplativa denotes thinking (in the narrow sense of the word), willing and judging, while vita activa means labor, work and action. All the activities of vita activa are related to politics, yet action is the most strongly related as it is based on the plurality of people and the possibility of uniting them (Arendt 2000, $11-12$ ). Thinking take place in solitude, it is not concerned with phenomena, it is focused on non-discursive truth. Action takes place in public, it happens among phenomena and together with others, it is oriented on discursive and valid opinion (Arendt 2006, 193 - 194, 197). The ability of thinking is not a will of cognition (will of certain and verifiable knowledge achievable through the intellect). Thinking denotes the need of 
the mind to go beyond limitations of knowledge, to achieve something more than collecting information and using it practically (Arendt 2006, 192, 197 - 197). Thinking is an activity which does not engender any impulse to undertake action, it does not provide positive instructions as to how to act, definitions of right and wrong, justice and injustice. Its validity and applicability in politics manifest themselves only in times of crisis, then it can protect against a catastrophe. Thinking is not manifested through knowledge, but through an ability to distinguish right from wrong, beauty from ugliness, truth from falsehood. In ordinary times, thinking is not useful, its products are uncertain and unverifiable. Thinking is destructive and auto-destructive, it undermines what has been established as well as its own results. Thinking does not establish once and for all what truth is, it only frees people from hasty judgements. It unfreezes what language (the medium of thinking) has frozen into concepts, sentences, definitions, doctrines (Arendt 2006, 152 - 153, 196 - 197, 205 - 206, 219).

Arendt believes that the power of judgement is what binds thinking and action together. This power allows thought not to be separated from reality, and it adds sense to action. She bases the conception of the power of judgement on Immanuel Kant's idea, yet in her understanding judging concerns not only esthetics but also morality and politics. Thinking as a dialogue of two-in-one destroys old convictions, which unleashes the power of judgement. Judging is the most political of all abilities of the human mind. This is an ability to state "this is wrong", "this is beautiful", "this is true". Judging as a dialogue with others denotes an ability to assess particular situations and phenomena without subjecting them to universal principles. Judging is based on seeing the universal in the particular, in a concrete case (Arendt 2006, 167, 220). Examples are a guidepost of the moral, political and historical thought (Arendt 2006, $172-173$ ).

The power of judgement consists in the ability of proffering an disinterested, impartial judgement. It is based on a common sense, which is common because it allows man to fit into a community with others. This happens by means of imagination, which is an ability to have in one's mind an image of something which is not present in a given moment, for instance other people's opinions. Thanks to imagination we can think assuming the perspective of other people (Arendt 2006, 168). If someone proffers a judgement that something is true, he demands other people to agree, because by judging he has already considered their point of view and thus hopes that his judgement is characterized by universality, although not by universal validity (Arendt 2006, 169 - 171, 174).

I believe that Arendt's thought, irrespective of which work is considered, presents only one model of judgement. It is only the spectator who controls the power of judgement. The political actor is not capable of determining the sense of his action, he does not recognize a complete picture of all the events in which he participates. He is 
too involved in action to do that. Action reveals itself fully only to a person who is not devoted to any matter. At the same time, the spectator does not turn his back on the world and others' opinions. Thus truth as an effect of the power of judgement appears in politics directly (Arendt 1985, 173, 176 - 177, 185 - 186; Arendt 2000, 211; 2006).

\title{
Bibliography
}

ARENDT, H. (1985): Prawda i polityka. Literatura na Świecie 6, 156 - 189.

ARENDT, H. (2005): Essays In Understanding, 1930 - 1954. New York: Schocken Books, 368 390.

ARENDT, H. (2006): Odpowiedzialność i władza sądzenia. Pruszyński i S-ka.

ARENDT, H. (2014): Korzenie totalitaryzmu. Warszawa: Świat Książki.

ARENDT, H. (2007): Polityka jako obietnica. Warszawa: Prószyński i S-ka.

ARENDT, H. (2000): Kondycja ludzka. Warszawa: Aletheia.

MACINTYRE, L. (2018): Post-Truth. Cambridge: MIT Press.

The Oxford Dictionaries. 2016. Word of the Year 2016 is... URL=https://en.oxforddictionaries.com/word-of-the-year/word-of-the-year-2016 [Accessed 25 September 2017].

\author{
Dorota Sepczyńska \\ Institiute of Philosophy \\ The Faculty of Humanities \\ University Warmia and Mazury in Olsztyn \\ ul. Kurta Obitza 1 \\ 10-725 Olsztyn \\ Poland \\ e-mail: sep@uwm.edu.pl
}

